\title{
Nutritional Value of Some Local Mushroom Species of Nepal
}

\section{Akkal Deo Mishra \& Manju Mishra}

\begin{abstract}
A study on the nutrients of cultivated and wild mushrooms as a sample analysis is carried out. The variation of chemical constituents based on the species, substratum and season has been observed for three cultivated species namely Agaricus bisporus, Pleurotus sajorcaju and Laccaria leccata alongwith one wild species namely Laetiporus sulphureus. The observations have been made for saw dust, paddy straw and wheat straw as substratum. Saw dust is found to produce higher yield followed by paddy straw in summer season as compared to winter vegetation. On the average $1.5 \mathrm{~kg}$ of saw dust produced $1 \mathrm{~kg}$ of mushroom.

Some principal nutrients like carbohydrates, amino acids, proteins, fats, minerals, fibre and ash, moisture content, etc. are estimated from the mentioned mushroom species. The maximum amount of nutrients contained in 100gm of dry mass is 90\% moisture, 15\% fibre and ash, 8\% carbohydrates, $12 \%$ amino acids, $32 \%$ proteins and $2.5 \%$ fat contents among the mushroom species studied. These mushrooms possess considerable amount of minerals like sodium, potassium, calcium, iron, phosphorus, etc. The maximum amount of these mineral elements in the mushrooms under experiment is $5 \%$ sodium, $6 \%$ phosphorus, $4 \%$ potassium, $2.5 \%$ calcium and $3 \%$ iron in straw based vegetation grown in summer season.

The mushroom species studied have been tested against different fungal and bacterial strains to observe their microbiological activities by using their biomass extract. They are found mild to moderate in antifungal and antibacterial activities. The wild species have shown higher potentiality against in vitro tested microbes as compared to cultivated mushrooms under experiment.
\end{abstract}

Keywords: Substratum, nutrients, extraction, saprophytes, antimicrobial.

\section{Introduction}

Mushroom is a saprophytic plant which feeds on dead and decaying organic matters. These are cosmopolitan in natural occurrence. Most of the mushrooms are wild, yet considerable species are cultivated worldwide. About 38,000 species of mushrooms are known in the world, out of which around 2,000 species are edible, more than 1,000 
species are poisonous (Chang, et al, 1995).

China, India, Greece, France, Netherlands, Tiwan, Thailand, Germany, Vietnam, UK, USA, etc. countries in the world use mushroom with different specifications of delicious food (Aneja,1996). Nepalese rural tribes such as Sherpa, Tamang, Tharu, Newar, Gurung, Chepang, Rai, Limbu, etc. have been utilizing this indigenous form of food from time immemorial (Bhandary, 1985). Mushroom serves as reliable openly accessible and less expensive article of food among rich and poors. The fast growing habit of mushroom has received a remarkable interest in recent times with the realization of delicious food with high nutritional and medicinal values. Mushroom is good oxygen carrier and adaptogen (Mehrotra, 1990). It has been used as traditional medicinal article in China, Japan, Korea, Thailand, Germany, Vietnam, UK. USA. etc. countries. Use of mushroom as food checks arthritis, hepatitis, diabetes, cancer, heart problems, chest problems, skin diseases, diuretics, ulcer, constipation, asthma, chronic, bronchitis, etc (Dube, 1992). Mushrooms are reported to act as detoxicant, cardiotonic, cold tonic, anticholesterol, blood pressure regulator, muscular relaxant, energy tonic, etc.

Mushroom has got diverse applications as food articles such as vegetable, soup, food additive, edible powder, water extract, alcoholic extract, tonic capsule,etc(Jayaraman,1992 and Joshi, 2005). Mushrooms contain various nutritional components like carbohydrates, adenosines, terpenoids, hormones, proteins, vitamins, amino acids, fibres, minerals, essential oils, steroids, etc.

Nepal is an agricultural country with diverse habitats for mushroom cultivation. Melamchi, Hele, Phulchoke, Sing Gompa, Ghorepani, etc. represent best sites for Himalayan fungal flora (Aryan, 2005). In addition to this mountains and midmountainous reasons of Nepal from east to west are rich in wild and cultivated mushroom species. Some work has been done about the survey of mushroom species in Nepal which reveals that there are about 1,000 species of conspicuous mushroom in our country (Bhandari, 2001). It has been noticed that although considerable work has been done for the collection and identification of Nepalese mushrooms but their chemical analysis for nutritional and medicinal values have not been attempted experimentally yet. It is estimated by the experts that there are about 200 edible varieties of mushroom in Nepal but less than 20 kinds only appear in local markets(Bhattarai,2001).

Professional mushroom cultivations have started in Nepal for 30 years in different parts. Some of the commonly cultivated mushroom species in Nepal are Agaricus bisporus (Gobre Chyau), Pleurotus sajor caju (Kanne chyau), Laccaria leccata (wood mushroom), Oyster, Volvarilla, Shitake, Ganodirma, etc. Among wild species, Laetiporus sulphureus (Rato Chyau), has drawn concern of people for its versatile food and medicinal values. Professional mushroom farming has been started in some districts, such as Kathmandu, Lalitpur, Bhaktapur, Kaski, Nuwakot, Dhading, Parbat, Baglung, Manag, Mustang, Myagdi, Palpa, Shyangja, Tanahun, Gulmi, Lamjung, Gorkha, Dhankuta, Sholukhumbu, Bhojpur, etc. Mushroom farming is done on different substratum like straw, husk, saw dust, cow dunk, wood, compost manure, banana leaves, sunflower leaves, etc. In Pokhara too, some varieties of cultivated mushroom 
Janapriya Journal of Interdisciplinary Studies, Vol. 2, No.1 (December 2013)

like Agaricus bisporus (Gobre Chyau), pleurotus sajor caju (Kanne chyau), Laccaria leccata (wood mushroom) and some wild species like Laetiporus sulphureus (Rato chyau), etc. are available in the market.

\section{Mushroom Species Studied}

The selected mushroom species under the investigation are:

\subsection{Cultivated mushroom species:}

a. Agaricus bisporus (Gobre chyau)

b. Pleurotus sajarcaju (Kanne chyau)

c. Laccaria leccata (Wood mushroom)

\subsection{Wild mushroom species:}

a. Laetiporus sulphureus (Rato chyau)

\section{Study Site}

Kaski of Gandaki and Baglung and Myagdi of Dhaulagiri zone are selected as study site of some cultivated and wild mushroom species.

A good number of people in Gandaki and Dhaulagiri zone are found to take even small quantity of mushroom in daily diet. Among the cultivated edible mushrooms, Agaricus bisporus (Gobre chyau), Lentinus edodes (shitake), volveriella volvacea (paddy straw), pleaurotus sajor caju (Oyster), etc. are commonly taken by local people as vegetable and soup. Similarly, Agaricus campestris (Khumb) and Laetiporus sulphureus (Rato chyau), etc. are most popularly used mushrooms in these areas.

Presently about five genera of edible mushrooms are cultivated viz, Agaricus lentinus, Volvariella, Pleurotus and Flammulina (Manandhar, 2007). In addition to these cultivated mushroom species, people have started farming some wild species like Laetiporus sulphureus (Rato chyau) as it is widely demanded medicinal fungus.

In Kaski, mushroom farming is done on commercial scale in mushroom houses with the mentioned species whereas in Baglung and Myagdi districts, it is done in smaller scales and in household farming also. The farming is run throughout the year, yet the market demand of mushroom is not fulfilled. Physiology of some commonly used mushrooms is given below.

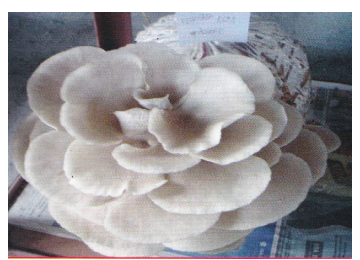

Fig.1: Kanne Chyau

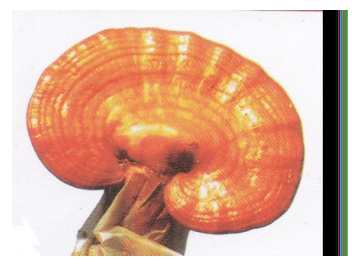

Fig. 2: Shitake Chyau

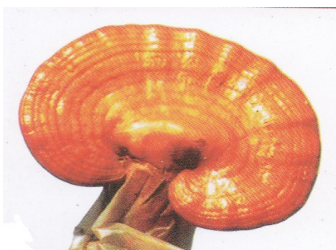

Fig.3: Ganoderma Chyau 
Janapriya Journal of Interdisciplinary Studies, Vol. 2, No.1 (December 2013)

\section{Experimental Methods and Materials}

\subsection{Collection of Mushroom Samples}

Three samples of cultivated species, viz, Agaricus bisporus (white button or Gobre chyau), pleurotus sajorcaju (Kanne chyau) and Laccaria leccata (wood mushroom) were collected from Beni, Baglung and Pokhara as representative centres of Myagdi, Baglung and Kaski districts respectively. $1 \mathrm{~kg}$ of fresh sample of each mushroom was collected in winter and summer seasons. Fresh weight of each sample was observed and the samples were packed in perforated polythene bags for their laboratory analysis. Mushrooms grown on wheat straw, rice straw and saw dust were collected under experiment.

One of the popular wild mushroom namely Laetiporus sulphureus (Rato chyau) was also collected in the amount of $1 \mathrm{~kg}$ in the similar way as that for three cultivated mushrooms. It was collected from nearby forest of the mentioned districts.

\subsection{Drying of Mushroom Samples}

All the collected mushroom samples were dried in dark room to prevent the decomposition and evaporation of essential compounds. Air drying was done completely to get dry mass under the experiment. The drying process was made effective with the aid of fast moving fans. It took about two months for complete drying of the mushroom sample.

\subsection{Estimation of Chemical Constituents}

Different mushroom samples under experiment were subjected to the estimation of chemical constituents by taking 100 gms of each sample. The estimation was done twice in a year, i.e. one for winter and another for summer vegetation for same species and for the same constituents. On the top of this the estimation was done for different substratum which includes wheat straw, paddy straw, and saw dust and agro-waste compost (Aneja, 1996 and Bansal, 1994). The samples were analyzed for moisture content, fiber and ash, carbohydrates, amino acids, proteins, fats and minerals. Airdried mushroom samples were grinded into fine powder followed by chemical analysis by different prescribed methods as mentioned below.

\subsubsection{Moisture Content}

It was determined by taking fresh weight of 100 gm of mushroom samples followed by taking the weight of completely dried sample. For drying of the samples, 100 gms of fresh mass was chopped into fine powder followed by absorption of water content in the bed of blotting paper for several turns. Then the mass was dried completely in room conditions for about two months. The dry mass was weighed to get constant weight which was then subtracted from the weight of fresh sample to obtain the moisture content in the sample. Moisture content in various samples of mushrooms was found within the range of $83-89 \%$ (table 1).

\subsubsection{Fibre and Ash Content}

100 gms of fresh sample was treated with dilute sulphuric acid (1\%) to dissolve all of the fleshy mass leaving behind residue which is fibre and ash present in the sample. The residue was dried in air completely till getting constant weight. The amount differs 
Janapriya Journal of Interdisciplinary Studies, Vol. 2, No.1 (December 2013)

in winter and summer vegetations as well as for the nature of the substratum used for the cultivation of mushrooms. The fibre and ash content was found within the range of $7.0-15 \%$ in the sample studied (table 1 ).

\subsubsection{Carbohydrates}

The amount of carbohydrates present in 100 gms of the dry sample was determined by Benedict's method. In this method, $100 \mathrm{ml}$ ethanolic extract of 100 gms of powdered mushroom sample was titrated against Benedict's reagent. $10 \mathrm{ml}$ of Benedict's reagent was taken in a conical flask and titrated against standard solution of sugar $(0.5 \%$ solution $)$. The volume of sugar solution was noted at the end point whereby the disappearance of white precipitate occurs. Similarly, the titration was done with unknown sugar solution, i.e. mushroom extract and the volume was noted. From the observations, $1 \mathrm{ml}$ of Benedict's reagent is equivalent to $0.05 \mathrm{mg}$ of sugar in the standard solution. $10 \mathrm{ml}$ of unknown sugar solution was consumed against $10 \mathrm{ml}$ of Benedict's reagent under experiment.

$10 \mathrm{ml}$ of ethanolic extract $\quad=0.5 \mathrm{mg}$ of carbohydrate

$100 \mathrm{ml}$ of ethanolic extract $\quad=5.0 \mathrm{mg}$ of carbohydrate

It means $100 \mathrm{gm}$ of mushroom contains $5.0 \mathrm{mg}$ of carbohydrate.

The titration was performed with each sample of mushrooms in the similar way to obtain the amount of carbohydrate contained in them (table 1).

\subsubsection{Amino Acids}

The amount of amino acids collectively in mushroom samples was determined by colorimetric method. $100 \mathrm{gm}$ of powder of dry sample of mushroom under experiment was digested with ethanol to get $100 \mathrm{ml}$ of extract. For the estimation of composite amino acids, $2 \mathrm{ml}$ of the extract was taken in a test tube followed by dilution with $10 \mathrm{ml}$ of distilled water. Then, $2 \mathrm{ml}$ of ninhydrin solution was added in the test tube and boiled in water bath for about 15 minutes. The content was cooled and $1 \mathrm{ml}$ of $50 \%$ ethanol was added to observe pink colour which was measured in a colorimeter to obtain the concentration of amino acids. Prior to this, colorimeter analysis of standard amino acid was performed for comparative study with reference sample. Standard solution of any amino acid was prepared by dissolving $5 \mathrm{mg}$ of amino acid in $10 \mathrm{ml}$ of $0.1 \mathrm{~N}$ hydrochloric acid. Estimation of amino acids in all the samples was done in the similar way. The amount of amino acids differs in the samples tested which ranges within 3.0 to $12.0 \mathrm{mg} / 100 \mathrm{gm}$ of the dry mass of mushrooms (table 1 ).

\subsubsection{Proteins}

Estimation of proteins was carried out by kjeldahl's method which involves the digestion of the ethanolic extract with conc-sulphuric acid to get ammonium sulphate. The solution of ammonium sulphate was then reacted with standard sodium hydroxide solution to liberate ammonia completely and thus liberated ammonia was absorbed in excess of N/10 hydrochloric acid. Unused acid was determined by titration with N/10 sodium hydroxide solution, so that the consumed hydrochloric acids is determined. 
Janapriya Journal of Interdisciplinary Studies, Vol. 2, No.1 (December 2013)

On knowing the amount of acid used to absorb ammonia liberated from ammonium sulphate, the amount of ammonia or free nitrogen can be calculated by applying normality equation. The amount of ammonia is directly proportional to the amount of protein in the mushroom sample.

$1000 \mathrm{ml} \mathrm{N}-\mathrm{HCl} \equiv 1000 \mathrm{ml} \mathrm{N}-\mathrm{NH}_{3} \equiv 17 \mathrm{gm}$ of $\mathrm{NH}_{3} \equiv 14 \mathrm{gm}$ of $\mathrm{N}_{2}$

On an average most of the proteins have $16 \%$ nitrogen in their composition. In other words, $1 \mathrm{mg}$ nitrogen equals $6.25 \mathrm{mg}$ protein. Thus, by finding out the amount of ammonia or nitrogen from a known amount of mushroom sample, calculation of amount of protein present in that sample can be done by multiplying the value with 6.25. The estimation procedure was repeated in similar way for all the samples of mushrooms. Various samples contained $20-32 \%$ of protein in the dry mass (table 1 ).

\subsubsection{Fats}

The amount of fat content in mushroom samples was determined by saponification value, which involves alkaline hydrolysis of fats or oils followed by back titration with unused alkali by using standard acid. The amount of consumed alkali thus was calculated from which the concentration of fatty acids was observed which is equivalent to the fats or the oils present in mushroom samples. $100 \mathrm{gm}$ of dry sample of mushroom was subjected to extraction with $4 \times 25 \mathrm{ml}$ of ethanol. The extract was then hydrolyzed with $50 \mathrm{ml}$ of $\mathrm{N} / 10 \mathrm{KOH}$ solution which is an excess amount. $10 \mathrm{ml}$ of resulted solution was taken in a conical flask and few drops of phenolphthalein was added as indicator followed by titration against $\mathrm{N} / 10$ solution of $\mathrm{HCl}$ to find out the actual amount of $\mathrm{KOH}$ solution consumed by the fatty acid. On knowing the amount of standard $\mathrm{KOH}$ consumed by fats or oils in the form of fatty acids, the concentration of them can be calculated by applying normality equation. Hence, the percentage composition of fats in mushroom samples was calculated. It arises in different species and according to the nature of substratum materials, which ranges from 0.5 to $2.5 \%$ (table 1 ).

\subsubsection{Minerals}

Minerals were detected and estimated by flame photometry and usual inorganic analytical methods. Ethanolic extract of 100 gms of dry mass of mushroom sample was used for identification and estimation of these elements in their respective compounds or salts. Flame photometry was adopted for the identification of $\mathrm{Na}, \mathrm{K}, \mathrm{Ca}$, etc. A bright golden yellow, pale violet and brick red colours to the flame indicates the presence of $\mathrm{Na}, \mathrm{K}$ and $\mathrm{Ca}$ ions is the mushroom extract respectively. Similarly, formation of blue colour with potassium ferricyanide solution indicates the presence of iron in the test sample. The amount of these minerals was determined by gravimetric analysis which involves the precipitation of metal ions followed by weighing to calculate the amount of the metal ions contained in $100 \mathrm{gms}$ of dry mushroom sample. Sodium was precipitated out as yellow crystalline solid by treating ethanolic solution with zinc uranyl acetate. On the other hand potassium was obtained as orange red precipitate by reacting the test solution with dipicryl amine. Calcium was obtained as yellow precipitate by the treatment of ammonium sulphide and dihydroxy tartarate osazone with the ethanolic extract of mushroom samples. Iron was precipitated as ferric hydroxide to get ferric 
oxide from which iron was estimated. In this estimation procedure, the precipitate of each metal ion was filtered off and the next ion was precipitated out from the filtrate. In the similar way, phosphorus was estimated as phosphate in the test samples. The amount of these minerals slightly differs in mushroom samples (table 2).

\section{Microbiological Screening}

Mushrooms have been reported to possess different antimicrobial compounds and thus are extensively used as medicinal herbs (Bhattarai, 2001). Both cultivated and wild mushrooms have shown some antifungal and antibacterial activities. The biomass of mushroom species was screened in vitro against three fungal strains namely Aspergillus niger, Alternaria solani and Candida albicans by paper dise diffusion method (Karanagh, 1983) and three bacterial strains namely Bacillus substilis, Staphylococus aureus and Salmonella typhi by cup diffusion method (Evans, 1985). Salicylic acid and oxytetracycline were used as standard drugs for antifungal and antibacterial screenings. Different mushroom samples showed mild to moderate antimicrobial activities (table 3).

\section{Results and Discussion}

\subsection{Chemical Constituents}

Paddy straw, wheat straw and saw dust were used as substratum for the growth of mushroom species separately. The vegetations were examined twice in a year, i.e., in winter and summer seasons. Saw dust has been proved an excellent substratum for mushroom cultivation. $1.5 \mathrm{~kg}$ of saw dust produced $2 \mathrm{kgs}$ of mushroom. Paddy straw and wheat straw produced some lesser amount of mushrooms as compared to saw dust. $3 \mathrm{kgs}$ and $4 \mathrm{kgs}$ of paddy straw and wheat straw gave $1 \mathrm{~kg}$ of mushrooms respectively. The amount has been observed higher in summer season as compared to winter which may be due to temperature and humidity concerns. The summer season provides optimal temperature and humidity for mushroom growth. The effect of substratum on the productivity of mushrooms is shown is table 4 .

The vegetation is best in case of Laccaria leccata and Laetiporus sulphureus with saw dust where $1.5 \mathrm{~kg}$ and $2.0 \mathrm{~kg}$ of substratum produced $1.0 \mathrm{~kg}$ of respective mushrooms. But the farming on saw dust is limited as compared to paddy straw and wheat straw.

Agaricus bisporus was found to possess $89 \%$ moisture which is maximum of all the species and Laetiporus sulphureus contained least moisture, i.e. $83 \%$. Similarly, fibre and ash contents range from 7.0 to 15\% Laetiporus sulphureus contained $8 \%$ of carbohydrates which is highest among the species studied. Amino acid content was found in the range of 3.0-12.0\%. Agaricus bisporus contained $12.0 \%$ and Laetiporus sulphureus 3\%. The amount of proteins seemed to be comparative for all the species studied. It ranges from 20-32\% for straw based substratum. Agaricus bisporus contained the highest amount of proteins. Although mushrooms are considered to be fat-less herbs, they possess some fats and oil contents as well. This content is least among the nutrients studied under experiment. Fat content ranges in between $0.5-2.5 \%$ in different species of mushrooms. Among the mushroom species studied, Laetiporus sulphureus 
Janapriya Journal of Interdisciplinary Studies, Vol. 2, No.1 (December 2013)

contained $0.5 \%$ of fats and Agaricus bisporus contained 2.5\% (table 1). These were the observations for paddy straw based substratum and were found to be higher than for saw dust and wheat straw.

Table 1: Amount of nutrients in different species of mushrooms

(straw based substratum)

\begin{tabular}{|l|l|l|l|l|l|l|}
\hline \multirow{2}{*}{ Mushroom Species } & \multicolumn{7}{|c|}{ Chemical nutrients (mg/100gm of dry mass) } \\
\cline { 2 - 7 } & Moisture & Fibre and ash & Carbohydrates & Amino acids & Proteins & Fats \\
\hline 1. Agaricus bisporus & 89 & 7.0 & 5.0 & 12.0 & 32.0 & 2.5 \\
\hline 2. Pleurotus Sajorcaju & 87 & 10.0 & 6.0 & 10.0 & 28.0 & 2.0 \\
\hline 3. Laccaria leccata & 86 & 12.0 & 7.5 & 8.5 & 24.0 & 1.5 \\
\hline 4. Laetiporus sulphureus & 83 & 15 & 8.0 & 3.0 & 20.0 & 0.5 \\
\hline
\end{tabular}

Mushrooms are considered to be good source of different minerals. Although mushrooms may contain various mineral contents, only sodium, potassium, calcium, iron and phosphorus have been observed in this study. The amount of these minerals is shown in table 2 for straw based summer vegetation of four mentioned species. The amount of sodium ranges from 1.0 to $5.0 \%$ and that of phosphorus from 2.0 to $6.0 \%$. This indicated that the amount of phosphorus is higher than that of sodium. The amount of sodium and phosphorus is higher in Agaricus bisporus as compared to other species. The amount of potassium is less than that of sodium; it levels up from 0.5 to $4.0 \%$. Similarly, the amount of calcium is comparatively less in mushroom species. It ranges from 1.0 to 2.5\% Laetiporus sulphureus possessed least and Agaricus bisporus possessed highest amount of calcium. Mushrooms also contain a fair amount of iron. Its amount is higher than that of calcium which ranges from 0.5 to $3.0 \%$ among the mushroom species under experiment.

Table 2: Amount of minerals in different species of mushrooms

(straw based substratum)

\begin{tabular}{|l|c|c|c|c|c|}
\hline \multirow{2}{*}{ Mushroom species } & \multicolumn{5}{|c|}{ Mineral contents (mg/100gm of dry mass) } \\
\cline { 2 - 6 } & $\mathrm{Na}$ & $\mathrm{P}$ & $\mathrm{K}$ & $\mathrm{Ca}$ & $\mathrm{Fe}$ \\
\hline 1.Agaricus bisporus & 5.0 & 6.0 & 4.0 & 2.5 & 3.0 \\
\hline 2.Pleurotus Sajorcaju & 3.5 & 4.5 & 2.5 & 2.0 & 2.0 \\
\hline 3. Laccaria leccata & 2.0 & 3.5 & 1.5 & 1.5 & 1.0 \\
\hline 4.Laetiporus sulphureus & 1.0 & 2.0 & 0.5 & 1.0 & 0.5 \\
\hline
\end{tabular}

\subsection{Microbiological Screening}

Mushrooms possess antifungal and antibacterial activities due to presence of some medicinal compounds. In vitro antifungal and antibacterial screening revealed that the wild species are more potential against microbes. Laetiporus sulphureus showed 
Janapriya Journal of Interdisciplinary Studies, Vol. 2, No.1 (December 2013)

moderate antimicrobial activities. Agaricus bisporus and Pleurotus sajorcaju showed very weak activities whereas Laccaria leccata proved to be mild against the tested strains of fungi and bacteria. This mild to moderate antimicrobial activities has made mushrooms popular food article as well as medicinal herb for their wider spectrum of users. Antimicrobial screening has supported the age-long tradition of mushrooms to be taken as food and medicinal dose.

Table 3: In vitro antifungal and antibacterial activities of different mushroom samples

\begin{tabular}{|l|c|c|c|c|c|c|}
\hline \multirow{2}{*}{\multicolumn{1}{c|}{ Mushroom Species }} & \multicolumn{3}{|c|}{ Fungal strains * } & \multicolumn{3}{c|}{ Bacterial strains ** } \\
\cline { 2 - 7 } & $\begin{array}{c}\text { Aspergillus } \\
\text { niger }\end{array}$ & $\begin{array}{c}\text { Alternaria } \\
\text { Solani }\end{array}$ & $\begin{array}{c}\text { Candida } \\
\text { albians }\end{array}$ & $\begin{array}{c}\text { Bacillus } \\
\text { subtilis }\end{array}$ & $\begin{array}{c}\text { Staphylococcus } \\
\text { aureus }\end{array}$ & $\begin{array}{c}\text { Salmonella } \\
\text { typhi }\end{array}$ \\
\hline 1.Agaricus bisporus & + & - & + & + & ++ & + \\
\hline 2.Pleurotus sajorcaju & + & + & + & + & + & + \\
\hline 3.Laccaria leccata & + & + & ++ & - & + & ++ \\
\hline 4.Laetiporus sulphureus & + & ++ & ++ & + & + & + \\
\hline Salicylic acid/ oxytetracycline & +++++ & +++++ & +++++ & +++++ & ++++ & ++++ \\
\hline
\end{tabular}

* Reference drug, Salicylic acid: $-=$ No measureable activity, $+=2-7 \mathrm{~mm},++$ $=8-12 \mathrm{~mm},+++=13-17 \mathrm{~mm},++++=18-22 \mathrm{~mm},+++++=23-26 \mathrm{~mm}$.

** Reference drug, Oxytetracycline: $-=$ No measurable activity, $+=3-8 \mathrm{~mm},++=$ 9-13mm, $+++=14-18 \mathrm{~mm},++++=19-23 \mathrm{~mm},+++++=24-28 \mathrm{~mm}$.

Table 4: Effect of substratum on the productivity of mushroom

\begin{tabular}{|l|c|c|c|}
\hline \multirow{2}{*}{ Mushroom species } & \multicolumn{3}{|c|}{ Amount of substratum in kgs to produce 1 kg of mushroom } \\
\cline { 2 - 4 } & Saw dust & Paddy straw & Wheat straw \\
\hline 1.Agaricus bisporus & 2.5 & 3.0 & 4.0 \\
\hline 2. Pleurotus Sajorcaju & 2.0 & 2.5 & 3.5 \\
\hline 3. Laccaria leccata & 1.5 & 2.5 & 3.0 \\
\hline 4.Laetiporus sulphureus & 2.0 & 3.0 & 3.5 \\
\hline
\end{tabular}

\section{Conclusion}

Western region is much rich in mushroom cultivation. Kaski, Baglung and Myagdi districts come in front line in this region for mushroom cultivation. Local peoples use some wild mushrooms as well. This food article has been cultivated throughout the year under different substratum like paddy straw, wheat straw, saw dust, agro-wastes compost, etc. Among the various mushroom species cultivated here are Agaricus bisporus, Pleurotus sajorcaju, and Laccaria leccata, etc. One of the wild mushroom species-Laetiporus sulphureus is found popular for its food as well as medicinal values. 
The production on saw dust is higher followed by paddy straw. On the top of this summer vegetation yield good amount as compared to winter and other vegetations which may be due to optimal temperature and humidity in summer season in this region.

The mushroom species mentioned above possess high protein and low fat contents. They possess almost $90 \%$ moisture, $15 \%$ fibre and ash, $8 \%$ carbohydrate, $12 \%$ amino acids, $32 \%$ proteins and $2.5 \%$ fat contents as the maximum amount among the mushroom species studied. There occurs a slight variation in the amount of these nutrients based on the mushroom species. These mushrooms possess considerable amount of minerals like sodium, phosphorus, potassium, calcium, iron, etc. The maximum amount of these minerals present in the mentioned mushrooms is $5 \%$ sodium, $6 \%$ phosphorus, $4 \%$ potassium, $2.5 \%$ calcium and 3.0\% iron in straw based substratum in summer season.

The mushroom species studied were found mild to moderate in antifungal and antibacterial activities. The wild mushrooms were more potential against the tested microbes as compared to the cultivated mushrooms.

\section{Acknowledgement}

The authors are grateful to Nepal Academy of Science and Technology (NAST), Khumaltar, Lalitpur, for providing fund to conduct this research work. Tribhuvan University, Prithvi Narayan Campus, Department of Chemistry and Department of Microbiology, Pokhara, deserve sincere thanks for providing available laboratory facilities. Thanks are offered to local people and mushroom professionals for extending co-operation during the research period.

\section{References}

Aneja, K. R. (1996). Experiments in microbiology, plant pathology, tissue culture and mushroom cultivation, (2 ${ }^{\text {nd }}$ ed.). New Delhi: Wishwa Prakashan.

Aryan, T. R. (2005). Mushroom poisoning problem in Nepal and its migration, fungi, USA:

Aryan, T. R. (2008). Oyster mushroom cultivation practical in Nepal. The mushroom growers News Letter, Vol. XVI, USA.

Aryan, T. R. (2008). The history of mushroom cultivation in Nepal. The Mushroom Growers News Letter, Vol. XVIII, USA.

Basal, R. K. (1994). Laboratory manual of organic chemistry. New Delhi: Willey Eastern LTD.

Bhandary H. R. (1985). Mushrooms, Nepal natures paradise. (Ed.) T. C. Majupuria.

Bhattarai, T. B. (2001). Practical biochemistry. Kathmandu: Bhundipuran Publication.

Chang T. S. (1995). Edible mushrooms and their cultivation. Hong Kong: Hong Kong University Press. 
Janapriya Journal of Interdisciplinary Studies, Vol. 2, No.1 (December 2013)

Chang, S. T. (1989). Miles, P.G., edible mushrooms and their cultivation. USA: CRC Press.

Dube, H. C. (1992). A textbook of fungi, bacteria and viruses. New Delhi: Vikas Publishing House Pvt. Ltd.

Evans, E. G. \& Gentles, J. C. (1985). Essentials of medicinal microbiology. UK: Edinburgh.

Jayaraman, J. (1992). Laboratory manual of biochemistry. New Delhi: Willey Eastern LTD.

Joshi, T. R. (2005). Miracle of ganotherapy. Kathmandu: Sajha Prakashan.

Karanagh, F. (1983). Analytical microbiology. New York: Academic Press.

Manandhar, K. L. (2007). Centre for agricultural technology. Mushroom Cultivation in Nepal, NAST News Letter.

Mehrotra, R. S. \& Aneja, K. R. (1990). An introduction to mycology. New Delhi: Wiley Eastern Ltd.

Shigere, Y. (2002). The magic effects of ganoderma. Japan: Kinki University Press. 